\title{
The influence of different dietary fat sources on tissue corticosterone concentration in rats
}

\author{
M. Stachońn ${ }^{1}$ E. Fürstenberg ${ }^{1}$, J. Gromadzka-Ostrowska ${ }^{1,3}$ \\ and K. Romanowicz ${ }^{2}$
}

\author{
${ }^{1}$ Department of Dietetics and Functional Foods, \\ Faculty of Human Nutrition and Consumer Sciences, Warsaw Agricultural University \\ Nowoursynowska 166, 02-787, Warsaw, Poland \\ ${ }^{2}$ The Kielanowski Institute of Animal Physiology and Nutrition, \\ Polish Academy of Sciences \\ 05-110 Jablonna, Poland
}

(Received 4 December 2000; accepted 20 April 2001)

\begin{abstract}
Forty-one rats were divided into six groups assigned to one of six diets containing three different fat types (sunflower oil, lard or 50:50 (w/w) blend of sunflower and lard) at one of two levels (5 or $30 \%$ ) to determine the effect on the corticosterone (Cs) level in the cytosol fraction of the adrenal glands, heart muscle and aorta in rats. Plasma cholesterol concentrations and body composition were also measured.

The diet with $5 \%$ lard significantly increased adrenal Cs compared with diets with $5 \%$ sunflower oil or $5 \%$ blend. Marked elevations in Cs level in the aorta were evident in rats fed diets with 5 and $30 \%$ sunflower oil in comparison with rats fed the 5 and $30 \%$ blend of lard and sunflower oil. In addition, the $\mathrm{Cs}$ level in the aorta in rats fed the diet with $30 \%$ sunflower oil was significantly higher than in rats fed the diet with $30 \%$ lard. The diet containing $5 \%$ sunflower oil markedly elevated the $\mathrm{Cs}$ level in rat heart muscle compared with the diet containing a $5 \%$ blend of the two fats. Unexpectedly, there were no significant effects of the experimental diets on plasma cholesterol concentrations. Moreover, rats fed diets containing 30\% fat had higher body dry matter and fat percentages, but lower protein and ash percentages compared with the rats fed diets containing $5 \%$ fat. The percentages of fat, protein and ash in the body were not affected by the type of dietary fat, but rats offered lard diets had a higher percentage of dry matter and fat than rats fed mixed fat diets.
\end{abstract}

KEY WORDS: corticosterone, fatty acids, rats, heart, aorta, adrenals

${ }^{3}$ Corresponding author 


\section{INTRODUCTION}

A number of studies have shown that the quantity and quality of the diet may exert an influence on hypothalamic-pituitary-adrenal (HPA) axis activity, mainly on the secretion of glucocorticoids (Endozien et al., 1978; Tannenbaum et al., 1997; Leibowitz et al., 1998). This secretion is, among other factors, modulated by dietary fat, namely free fatty acids. It secms that fat is one of the macronutrients that markedly influence HPA axis activity; the physiological effects of this macronutrient depend on its level and source in the diet, i.e. the type and amount of fatty acids (FAs) and cholesterol. On the other hand, the HPA axis is an endocrine pathway that, in addition to its numerous functions, promotes lipolysis and elevated FFA levels in the blood. Nevertheless, it was shown that FAs activate the secretion of glucocorticoids (GCs) in adrenal glands (Widmaier et al., 1992).

It is believed that the effects of a high-fat diet mimic those of ACTH on GCs levels. On the other hand, it is possible that the effects of a high-fat diet may be mediated by these hormones (Tannenbaum et al., 1997). This applies mainly to the risk of abdominal obesity, coronary heart disease (CHD), noninsulin-dependent diabetes mellitus (NIDDM), and other diseases (Lipid Research Clinics Program, 1984; Storlien et al., 1986; American Diabetes Association, 1987; Malozowski et al., 1990; Zimmet and Baba, 1990; Golay and Bobbioni, 1997). Glucocorticoids, in addition to their numerous other functions, regulate cardiovascular homeostasis via the effects of circulating components generated within the adrenals and also through local synthesis (Silvestre et al., 1998). Prolonged excess of GCs may lead to various diseases. The corticosterone (Cs) level in heart muscle and vessels, target tissues for this glucocorticoid, reflects its uptake by these tissues, therefore gives a chance to estimate the risk of developing cardiovascular diseases. A diet with a proper FA profile may minimize this risk. Additionally, excess dietary cholesterol may also lead to occurrence of cardiovascular disease. The composition of fatty acids of dietary fats influences the plasma concentration of cholesterol (Ghatak et al., 1992) and is, therefore, considered of major importance in the etiology of coronary heart disease (Grundy, 1989; Hegsted, 1991). High consumption of saturated fats and cholesterol is associated with higher blood cholesterol and higher frequency of myocardial infarction and death from CHD. On the other hand, a diet rich in polyunsaturated fatty acids and monounsaturated fatty acids may prevent CHD and many other diseases (Sinclair, 1984; Leaf and Weber, 1988; Harris, 1989; Mensink and Katan, 1989; Oliver et al., 1989).

The present study was performed to examine the influence of dietary fat on Cs concentration in target tissues, an issue about which there is still very little knowledge. 


\section{MATERIAL AND METHODS}

\section{Animals and diets}

Forty-one male Wistar rats weighing 110-130 $\mathrm{g}$ at the beginning of the experiment were used. The animals were housed in individual stainless steel cages and maintained at $23^{\circ} \mathrm{C}$ with a $12: 12 \mathrm{~h}$ light-dark cycle. After a three-day adaptation period, the rats were randomly divided into six groups and assigned to one of six diets containing three different fat types (sunflower oil, lard or $50: 50 \mathrm{w} / \mathrm{w}$ blend of sunflower oil and lard) at one of two levels (normal, 5 , or high, 30\%). The composition of test diets and their fatty acid contents calculated from data given by $\mathrm{Ku}-$ nachowicz et al. (1998) are shown in Tables 1 and 2, respectively. The rats were given free access to the diet and tap water throughout the 4-week experiment. Daily intake of food was measured for each animal after correction for spilled food; body weight was monitored every three days.

TABLE 1

Formulation and chemical composition of diets

\begin{tabular}{|c|c|c|c|c|c|c|}
\hline Diet & $\begin{array}{c}A-5 \% \\
\text { sunflower } \\
\text { oil }\end{array}$ & $\begin{array}{c}\text { B }-30 \% \\
\text { sunflower } \\
\text { oil }\end{array}$ & $\begin{array}{c}\mathrm{C}-5 \% \\
\text { lard }\end{array}$ & $\begin{array}{c}\mathrm{D}-30 \% \\
\text { lard }\end{array}$ & $\begin{array}{c}E ̈-5 \% \\
\text { sunflower } \\
\text { oil + lard }\end{array}$ & $\begin{array}{c}F-30 \% \\
\text { sunflower } \\
\text { oil + lard }\end{array}$ \\
\hline \multicolumn{7}{|l|}{ Ingredients, $\mathrm{g} / \mathrm{kg}$} \\
\hline casein & 165 & 165 & 165 & 165 & 165 & 165 \\
\hline wheat starch & 693 & 444 & 693 & 444 & 693 & 444 \\
\hline potato starch & 50 & 50 & 50 & 50 & 50 & 50 \\
\hline fat & 50 & 300 & 50 & 300 & 50 & 300 \\
\hline vitamin mixture ${ }^{l}$ & 30 & 30 & 30 & 30 & 30 & 30 \\
\hline mineral mixture ${ }^{2}$ & 10 & 10 & 10 & 10 & 10 & 10 \\
\hline choline chloride & 2 & 2 & 2 & 2 & 2 & 2 \\
\hline L-methionine & 1 & 1 & 1 & 1 & 1 & 1 \\
\hline \multicolumn{7}{|l|}{ Nutrient, $\mathrm{g} / \mathrm{kg}$} \\
\hline dry matter & 888.0 & 935.4 & 894.1 & 925.6 & 892.7 & 930.8 \\
\hline protcin & 153.4 & 146.2 & 145.5 & 144.5 & 146.4 & 145.9 \\
\hline fat & 37.5 & 307.7 & 62.2 & 316.1 & 57.8 & 309.9 \\
\hline ash & 29.4 & 27.8 & 27.6 & 27.5 & 28.9 & 27.9 \\
\hline $\mathrm{ME}, \mathrm{MJ} / \mathrm{kg}$ & 15.15 & 21.62 & 15.80 & 21.63 & 15.66 & 21.58 \\
\hline
\end{tabular}

1 vitamin mixture supplied (per kg diet): vit. A, $6000 \mathrm{IU}$; vit. $\mathrm{D}_{3}, 600 \mathrm{IU}$; vit. E, $30 \mathrm{IU}$; vit. $\mathrm{K}, 1.5 \mathrm{mg}$, PABA, $30 \mathrm{mg}$; inositol, $30 \mathrm{mg}$; niacin, $1.2 \mathrm{mg}$; Ca-pantothenate, $1.2 \mathrm{mg}$; riboflavin, $2.4 \mathrm{mg}$; thiamine, $1.5 \mathrm{mg}$; pyridoxine, $1.5 \mathrm{mg}$; folic acid, $0.6 \mathrm{mg}$; biotin, $0.12 \mathrm{mg}$; vit. $\mathrm{B}_{12}, 9 \mu \mathrm{g}$

2 mineral mixture supplied (per kg diet): $\mathrm{NaH}_{2} \mathrm{PO}_{4} \mathrm{H}_{2} \mathrm{O}, 7.35 \mathrm{~g} ; \mathrm{K}_{2} \mathrm{HPO}_{4}: 0.81 \mathrm{~g} ; \mathrm{K}_{2} \mathrm{SO}_{4}, 0.68 \mathrm{~g}$; $\mathrm{NaCl}, 0.306 \mathrm{~g} ; \mathrm{CaCO}_{3}, 0.21 \mathrm{~g} ; \mathrm{NA}_{2} \mathrm{HPO}_{4}, 0.214 \mathrm{~g} ; \mathrm{MgO}, 0.25 \mathrm{~g} ; \mathrm{C}_{3} \mathrm{H}_{4}(\mathrm{OH})(\mathrm{COO})_{2} \mathrm{Fe}, 55.8 \mathrm{mg}$; $\mathrm{ZnCO}_{3}, 8.1 \mathrm{mg} ; \mathrm{MnCO}_{3}, 42.1 \mathrm{mg} ; \mathrm{CuCO}_{3}, 3.33 \mathrm{mg} ; \mathrm{C}_{3} \mathrm{H}_{4} \mathrm{OH}(\mathrm{COOH})_{3}, 70.56 \mathrm{mg} ; \mathrm{KJ}, 72 \mu \mathrm{g}$ 
TABLE 2

Fatty acids content in experimental diets containing $5 \%(\mathrm{~A})$ and $30 \%(\mathrm{~B})$ fat $(\mathrm{g} / 100 \mathrm{~g})$ according to Kunachowicz et al. (1998)

\begin{tabular}{|c|c|c|c|c|c|c|c|}
\hline Diet & & $\begin{array}{c}A-5 \% \\
\text { sunflower } \\
\text { oi! }\end{array}$ & $\begin{array}{c}\mathrm{B}-30 \% \\
\text { sunflower } \\
\text { oil }\end{array}$ & $\begin{array}{c}\mathrm{C}-5 \% \\
\text { lard }\end{array}$ & $\begin{array}{c}\mathrm{D}-30 \% \\
\text { lard }\end{array}$ & $\begin{array}{c}E-5 \% \\
\text { sunflower } \\
\text { oil + lard }\end{array}$ & $\begin{array}{c}F-30 \% \\
\text { sunflower } \\
\text { oil + lard }\end{array}$ \\
\hline Miristic acid & $14: 0$ & 0 & 0 & 0.068 & 0.408 & 0.034 & 0.202 \\
\hline Palmitic acid & $16: 0$ & 0.318 & 1.908 & 1.331 & 7.983 & 0.825 & 4.946 \\
\hline Stearic acid & $18: 0$ & 0.183 & 1.098 & 0.749 & 4.494 & 0.466 & 2.796 \\
\hline Oleic acid & $18: 1$ & 0.965 & 5.793 & 2.093 & 12.555 & 1.529 & 9.174 \\
\hline Linoleic acid & $18: 2$ & 3.222 & 19.332 & 0.331 & 1.983 & 1.777 & 10.659 \\
\hline
\end{tabular}

Tissue collection

At the end of the experiment, the rats were etherized and blood samples were collected from the heart into heparinized tubes and centrifuged at $3000 \mathrm{~g}$ for 10 min; the plasma was stored at $-23^{\circ} \mathrm{C}$ until assayed for cholesterol concentration. Additionally, adrenal glands, heart and aorta were dissected, rinsed, blotted, weighed and snap frozen in liquid nitrogen for hormone determination; carcasses were frozen for chemical analyses.

\section{Radioimminoassays}

The corticosterone level in cytosol extracts of adrenal glands, heart and aorta was measured by radioimmunoassay (RIA) according to Stupnicki (1985). The assay sensitivity and intra- and inter-assay coefficients of variation were $10.0 \mathrm{pg} /$ $\mathrm{ml}, 3.2$, and $4.5 \%$, respectively. Tissue cytosol Cs concentrations were expressed in $\mathrm{ng}$ or $\mathrm{pg}$ per $\mathrm{mg}$ of cytosol protein determined by the method of Lowry et al. (1951).

\section{Plasma cholesterol}

The plasma cholesterol concentration was estimated by the method of Watson (Mangold and Bezzegh, 1974).

\section{Carcass analyses}

Chemical components (dry matter, protein, fat, ash) were determined in triplicate samples of autoclaved and homogenized carcasses by means of standard analytical methods according to AOAC (1960) (oven-drying, Kjeldahl method, diethyl ether-extraction and muffle-oven combustion, respectively). 


\section{Statistical analyses}

Data on plasma cholesterol and corticosterone concentration and body composition were subjected to two-way variance analysis (ANOVA) to determine the influences of fat type and fat level in the diet. When analysis of variance indicated significant differences $(\mathrm{P}<0.05)$, a multiple comparison was performed to compare group means using the Fisher's least significant differences (LSD) method. Finally, correlations between tissue corticosterone concentration and fatty acid intake (calculated from fat intake and fatty acid content in dietary fat) were also evaluated. The computations were performed using STATGRAPHICS Plus ver$\operatorname{sion} 4.1$.

\section{RESULTS}

\section{Food intake}

Daily food intake during the 28-day experiment was fat-level dependent (Table 3). Animals fed diets containing $5 \%$ fat (diets A, C, E) consumed significantly more food than rats receiving diets with $30 \%$ fat (diets B, D, F). Fat type, however, did not significantly affect food consumption. In addition, the amount of fat consumed and type of dietary fat significantly influenced consumption of the respective fatty acids. Although groups B, D and F consumed, as mentioned above, less food than other groups, the rats given high-fat diets ( $30 \%$ fat, diets B, D, F) consumed significantly more respective fatty acids than animals given low fat diets (5\% fat, diets A, C, E).

Final body weight and body weight gain

Despite differences in food consumption, final body weights did not significantly differ between dietary treatments, being: $226 \pm 4 \mathrm{~g} ; 217 \pm 5 \mathrm{~g} ; 231 \pm 5 \mathrm{~g} ; 225 \pm 6 \mathrm{~g}$; $226 \pm 3 \mathrm{~g} ; 224 \pm 7 \mathrm{~g}$ for groups A-F, respectively. Thus, neither fat type nor fat level in the diet influenced final body weights of the experimental groups. However, the body weight gains of rats receiving $5 \%$ fat diets, in comparison with the $30 \%$ fat groups, were slightly higher throughout the experiment (the $5 \%$ fat groups gained weight slightly faster than the $30 \%$ fat groups) (Table 3 ).

\section{Body composition}

Results from chemical analysis are summarized in Table 4. Due to technical problems, the results of groups A and B are means of 5 and 6 rats, respectively. 
Means and standard errors of growth rate and food intake traits of rats

TABLE 3

\begin{tabular}{|c|c|c|c|c|c|c|c|c|c|}
\hline \multirow[b]{2}{*}{ Diet } & \multirow{2}{*}{\multicolumn{2}{|c|}{$\begin{array}{c}\mathrm{A}-5 \% \\
\text { sunflower } \\
\text { oil }\end{array}$}} & \multirow{2}{*}{$\begin{array}{c}\mathrm{B}-30 \% \\
\text { sunflower } \\
\text { oil }\end{array}$} & \multirow[b]{2}{*}{$\begin{array}{c}\mathrm{C}-5 \% \\
\text { lard }\end{array}$} & \multirow[b]{2}{*}{$\begin{array}{c}\mathrm{D}-30 \% \\
\text { lard }\end{array}$} & \multirow{2}{*}{$\begin{array}{c}E-5 \% \\
\text { sunflower } \\
\text { oil +lard }\end{array}$} & \multirow{2}{*}{$\begin{array}{l}F-30 \% \\
\text { sunflower } \\
\text { oil + lard }\end{array}$} & \multicolumn{2}{|c|}{ Probability (P) } \\
\hline & & & & & & & & $\begin{array}{c}\text { fat } \\
\text { level }\end{array}$ & $\begin{array}{c}\text { fat } \\
\text { type }\end{array}$ \\
\hline $\mathrm{n}$ & & 6 & 7 & 7 & 7 & 7 & 7 & & \\
\hline Final body weight, $g$ & 226.3 & $3+3.9$ & $216.6 \pm 4.9$ & $230.8 \pm 5.1$ & $224.6 \pm 6.1$ & $225.9 \pm 3.2$ & $223.9 \pm 7.3$ & 0.1765 & 0.5159 \\
\hline Daily gain, g/day & 3.72 & $2 \pm 0.17^{a}$ & $3.23 \pm 0.14^{b}$ & $3.79 \pm 0.12^{\mathrm{a}}$ & $3.54 \pm 0.17^{\mathrm{sb}}$ & $3.74 \pm 0.15^{\mathrm{a}}$ & $3.39 \pm 0.16^{\mathrm{ah}}$ & 0.005 & 0.46 \\
\hline Food intake, g/100g/day & 7.29 & $9 \pm 0.12^{a}$ & $5.93 \pm 0.08^{b}$ & $7.23 \pm 0.12^{\mathrm{a}}$ & $6.0 \pm 0.13^{h}$ & $7.38 \pm 0.11^{\mathrm{t}}$ & $6.11 \pm 0.06^{\circ}$ & 0.0000 & 0.1943 \\
\hline $\mathrm{ME}$ intake, $\mathrm{kJ} / 100 \mathrm{~g} / \mathrm{day}$ & 110.48 & $8 \pm 1.78^{a}$ & $128.19 \pm 1.78^{b}$ & $114.23 \pm 1.96^{\mathrm{it}}$ & $129.95 \pm 2.71^{b}$ & $115.57 \pm 1.75^{\mathrm{a}}$ & $132.0 \pm 1.27^{\mathrm{b}}$ & 0.0000 & 0.3334 \\
\hline Protein intake, $\mathrm{g} / 100 \mathrm{~g} / \mathrm{day}$ & 1.12 & $2 \pm 0.02^{\circ}$ & $0.87 \pm 0.01^{\mathrm{c}}$ & $1.05 \pm 0.02^{b}$ & $0.87 \pm 0.02^{2}$ & $1.08 \pm 0.02^{\mathrm{ab}}$ & $0.89 \pm 0.01^{\mathrm{c}}$ & 0.0000 & 0.0968 \\
\hline \multicolumn{10}{|l|}{ Fatty acids intake, $g / 100 \mathrm{~g} /$ day } \\
\hline miristic acid $14: 0\left(*^{*} 10^{-2}\right)$ & & $0.0^{\mathrm{a}}$ & $0.0^{\mathrm{a}}$ & $0.492 \pm 0.008^{\mathrm{b}}$ & $2.45 \mathrm{I} \pm 0.05 \mathrm{I}^{\mathrm{c}}$ & $0.251 \pm 0.004^{d}$ & $1.235 \pm 0.012^{\mathrm{e}}$ & 0.0000 & 0.0000 \\
\hline palmitic acid $16: 0$ & 0.018 & $8+0.0004^{a}$ & $0.122 \pm 0.002^{b}$ & $0.125 \pm 0.002^{b}$ & $0.529 \pm 0.011^{\mathrm{s}}$ & $0.074 \pm 0.001^{\mathrm{sb}}$ & $0.285 \pm 0.045^{\circ}$ & 0.0000 & 0.0000 \\
\hline stearic acid $\quad 18: 0$ & 0.010 & $0 \pm 0.0002^{\mathrm{a}}$ & $0.068 \pm 0.001^{b}$ & $0.094 \pm 0.002^{c}$ & $0.397 \pm 0.008^{d}$ & $0.052 \pm 0.001^{\mathrm{e}}$ & $0.233 \pm 0.002^{f}$ & 0.0000 & 0.0000 \\
\hline oleic acid & 0.060 & $0 \pm 0.001^{\mathrm{a}}$ & $0.404 \pm 0.006^{\mathrm{b}}$ & $0.161 \pm 0.003^{c}$ & $0.678 \pm 0.04^{\mathrm{d}}$ & $0.123 \pm 0.002^{\mathrm{c}}$ & $0.548 \pm 0.005^{f}$ & 0.0000 & 0.0000 \\
\hline linoleic acid $18: 2$ & $0 . j 66$ & $6 \pm 0.003^{\mathrm{a}}$ & $1.118 \pm 0.015^{\mathrm{b}}$ & $0.0014 \pm 0.0001^{c}$ & ${ }^{c} 0.006+0.000 \mathrm{l}^{\mathrm{c}}$ & $=0.131 \pm 0.002^{\mathrm{d}}$ & $0.584 \pm 0.06$ & 0.0000 & 0.0000 \\
\hline
\end{tabular}

The influence of fat level and fat type in the dict on body composition of rats

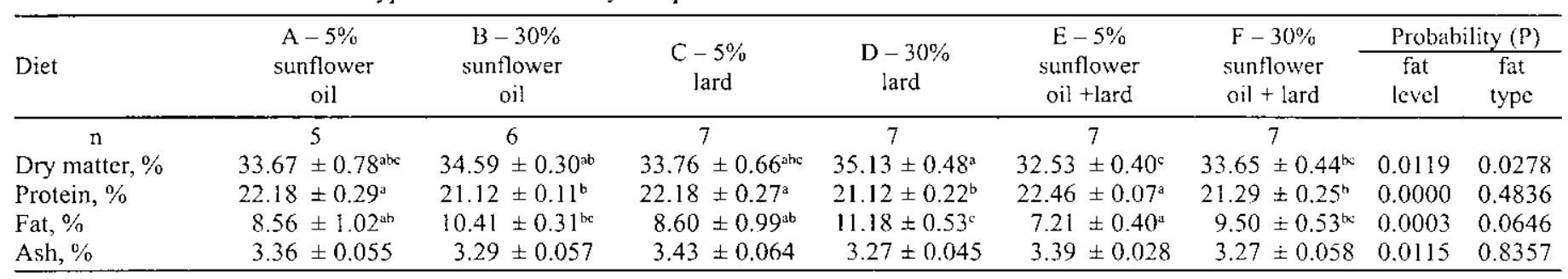

a.b,c $-\mathrm{P}<0.05$

TABLE 4 
Although no differences in final body weight were found between dietary treatments, rats differed in body composition depending on fat level and fat type. Rats fed diets containing $30 \%$ fat, when compared with rats given the fed $5 \%$ fat diets, had a significantly higher percentages of dry matter ( $34.45 \pm 0.30$ vs $33.28 \pm 0.31)$ and fat $(10.36 \pm 0.39$ vs $8.08 \pm 0.40)$ in the body. However, the percentages of protein and ash were significantly lower in these rats $(21.18 \pm 0.12$ vs $22.28 \pm 0.13$ and $3.28 \pm 0.03$ vs $3.39 \pm 0.03$, respectively).

The type of fat significantly influenced the body dry matter percentage $(P=0.0278)$. Rats offered lard diets and sunflower oil diets had a significantly higher percentage of dry matter ( $34.45 \pm 0.35$ and $34.17 \pm 0.40$, respectively) than rats fed mixed fat diets $(33.09 \pm 0.35)$. In addition, the fat percentage tended to be higher in rats fed diets with lard $(9.89 \pm 0.46)$ than in those receiving mixed fat diets $(9.35 \pm 0.46)$, however, no significant influence of fat type on body fat percentage $(\mathrm{P}=0.0630)$ was found. Protein and ash percentages were not affected by type of dietary fat, either $(\mathrm{P}=0.4836$ and $\mathrm{P}=0.8357$, respectively).

\section{Corticosterone concentrations in adrenal glands, heart and aorta}

A significant influence of dietary fat type on the corticosterone concentration in the cytosol of adrenal glands $(\mathrm{P}<0.05)$, heart $(\mathrm{P}<0.05)$ and aorta $(\mathrm{P}<0.003)$ was observed in the present experiment. The high fat groups $(\mathrm{B}, \mathrm{D}, \mathrm{F})$ did not differ in corticosterone concentration in adrenal glands. Significant differences were, however, found between groups fed $5 \%$ fat diets. The corticosterone concentration in the cytosol of adrenal glands was significantly higher in the 5\% lard group than in other two groups, the $5 \%$ sunflower oil and $5 \%$ oil plus lard groups (Figure 1).

Similarly, no significant differences in heart cytosol corticosterone concentrations were found between groups fed $30 \%$ fat diets containing sunflower oil, lard, or a mixture of sunflower oil and lard, while in the $5 \%$ fat groups, the corticosterone concentration in heart cytosol was significantly lower in rats consuming a mixture of animal and vegetable fat than in animals fed the diet containing sunflower oil (Figure 2).

The corticosterone concentration in the cytosol of the aorta was found to be significantly lower in rats fed mixed diets containing 5 and $30 \%$ fat than in animals offered dicts with a low or high level of sunflower oil. Moreover, the hormone concentration was about $50 \%$ lower $(\mathrm{P}<0.01)$ in group $\mathrm{D}$ receiving the $30 \%$ lard diet than in group $\mathrm{B}$ fed the diet containing sunflower oil at the same level (30\%) (Figure 3).

Statistical analysis did not reveal any significant influence of the level of dietary fat on corticosterone concentration in the cytosol of the body organs examined. 


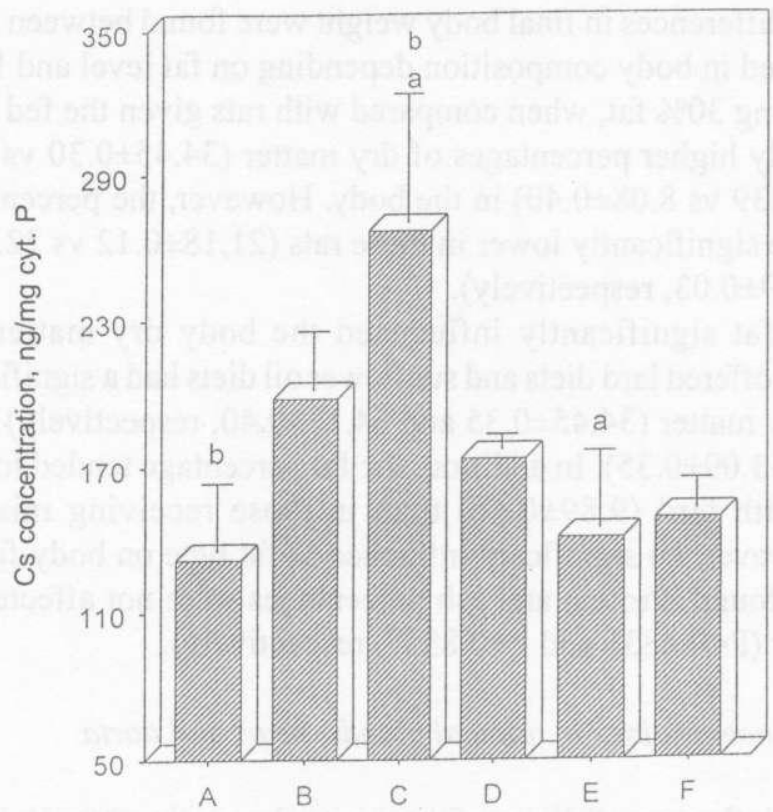

Diet groups

Figure 1. Corticosterone (Cs) concentration in adrenal gland cytosol fraction (ng/mg cytosol protein) The same letters $(a, b)$ indicate statistically significant differences between groups at $\mathrm{P}=0.05$

\section{Plasma cholesterol concentration}

It was shown that neither fat type nor fat level in the diet significantly influenced the plasma cholesterol concentration of the experimental animals. No significant differences were found between respective dietary treatments, either. The plasma cholesterol concentrations were: group A $102 \pm 18 \mathrm{mg} / 100 \mathrm{ml}$; B $101 \pm 24 \mathrm{mg} / 100 \mathrm{ml} ;$ C $93 \pm 10 \mathrm{mg} / 100 \mathrm{ml}$; D $109 \pm 12 \mathrm{mg} / 100 \mathrm{ml} ; \mathrm{E} 94 \pm 11 \mathrm{mg} /$ $100 \mathrm{ml} ; \mathrm{F} 96 \pm 18 \mathrm{mg} / 100 \mathrm{ml}$.

\section{DISCUSSION}

A large number of studies have addressed the question of the influence of dietary macroelements on the secretion of corticosterone (Endozien et al., 1978). With regard to diets that differ in fat level, no unequivocal conclusions can be drawn on the influence of the amount of fat in the diet on adrenal secretion of this glucocorticoid. The results obtained to date are often conflicting and sug- 


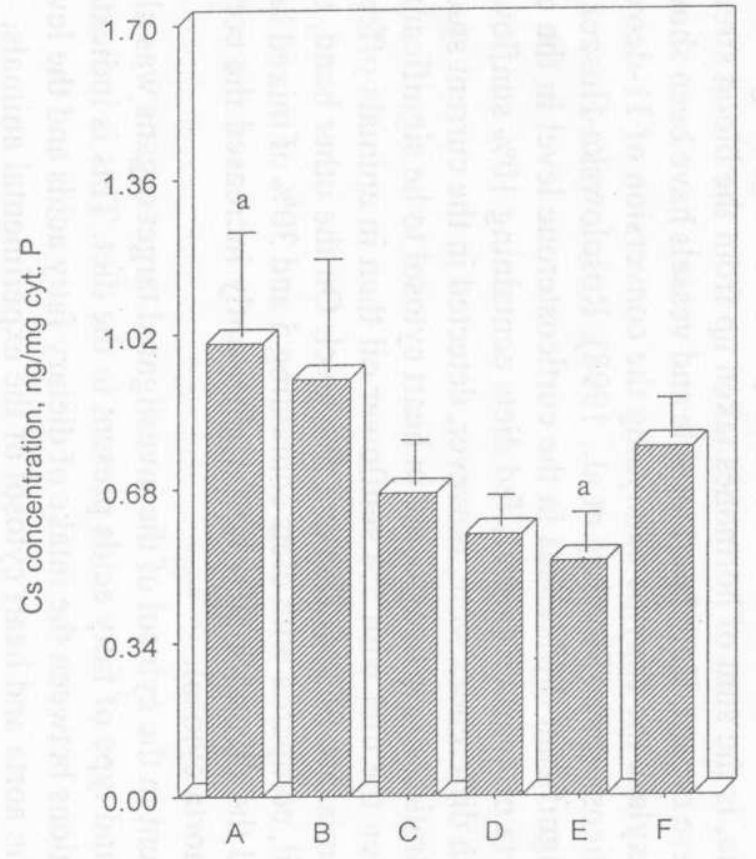

Diet groups

Figure 2. Corticosterone (Cs) concentration in heart muscle cytosol fraction (pg/mg cytosol protein). The same letters (a) indicate statistically significant differences between groups at $\mathrm{P}=0.05$

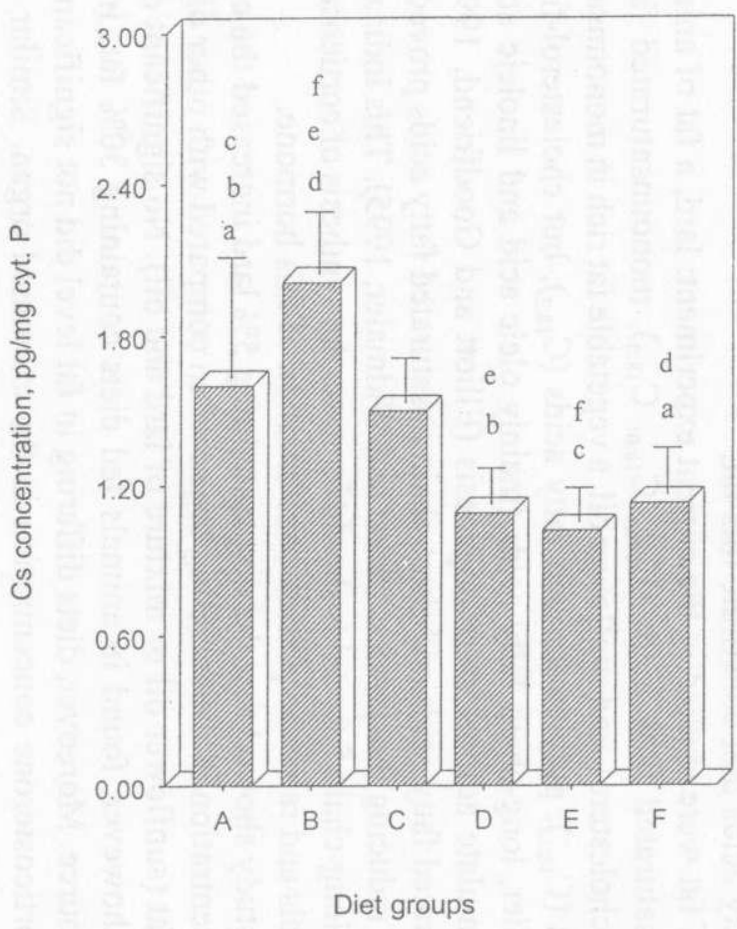

Figure 3. Corticosterone (Cs) concentration in aorta cytosol fraction ( $\mathrm{pg} / \mathrm{mg}$ cytosol protein). The same letters indicate statistically significant differences between groups at $\mathrm{P}<0.04$ (a), $\mathrm{P}<0.03$ (b), $\mathrm{P}<0.02$ (c,d) and $\mathrm{P}<0.01(\mathrm{e}, \mathrm{f})$ 
gest the possible significant impact of the type of fat in the diet and, more precisely, of the fatty acids that constitute this fat.

Two types of fat were studied in the current experiment: lard, a fat of animal origin, rich in saturated fatty acids $\left(\mathrm{C}_{14: 0}, \mathrm{C}_{16: 0}, \mathrm{C}_{18: 0}\right)$, monounsaturated fatty acids $\left(\mathrm{C}_{18: 1}\right)$ and cholesterol, and sunflower oil, a vegetable fat rich in monounsaturated fatty acids $\left(\mathrm{C}_{18: 1}\right)$, polyunsaturated fatty acids $\left(\mathrm{C}_{18: 2}\right)$, but cholesterol-free. As outlined earlier, long-chain fatty acids (mainly oleic acid and linoleic acid) significantly stimulate adrenal steroidogenesis (Elliott and Goodfriend, 1993). In addition, saturated fatty acids and short-chain unsaturated fatty acids proved to be ineffective in inducing this process (Sarel and Widmaier, 1995). This indicates that diets rich in long-chain fatty acids should increase the synthesis of corticosterone in the adrenals and raise the plasma concentration of this hormone.

The present study showed that the diet containing $5 \%$ lard increased the corticosterone concentration in the secreting organ when compared with other diets containing 5\% fat (sunflower oil or mixture of lard and oil). No significant differences, were, however, found in animals fed diets containing $30 \%$ fat, irrespective of fat source. Morcover, diets differing in fat level did not significantly influence the corticosterone concentration in the examined organ. Similar results were obtained from the study of Rosołowska-Huszcz et al. (2001). In this experiment the diets contained $10 \%$ fat from different sources and the lowest level of adrenal corticosterone was found in the group of rats fed a diet containing sunflower oil, while the lard diet significantly increased the level of this hormone in the secreting organ.

The glucocorticoid content determined in the cytosol of target organs, i.e. heart muscle and aorta, is the sum of hormones taken up from the blood stream and synthesized in these organs. Both heart muscle and vessels have been shown to express $11 \beta$-hydroxylase the enzyme catalyzing the conversion of 11 -deoxycorticosterone to corticosterone (Silvestre et al., 1998). Rosołowska-Huszcz et al. (2001) noted no significant differences in the corticosterone level in the cytosol of either the aorta or heart of animals fed diets containing $10 \%$ sunflower oil and $10 \%$ lard. Such differences were, however, detected in the current study. We found the concentration of corticosterone in heart cytosol to be significantly higher in animals given the diet with $5 \%$ sunflower oil than in animals offered the diet containing a mixture of both fats at a $5 \%$ level. On the other hand, the diet with sunflower oil, compared with diets containing 5 and $30 \%$ of mixed lard and sunflower oil and the diet with $30 \%$ lard, significantly increased the corticosterone content in aorta cytosol.

The hormone content in the cytosol of the investigated target organs was also affected by the level and type of fatty acids present in the diet. This is indicated by significant correlations between the intake of dietary fatty acids and the level of corticosterone in the aorta and heart cytosol of the experimental animals. 
Such a correlation was found in the current study - the intake of $\mathrm{C}_{14: 0}$ and hormone levels in the heart and aorta were negatively correlated, with correlation coefficients of $\mathrm{r}=-0.47, \mathrm{P}<0.01$ and $\mathrm{r}=-0.54, \mathrm{P}<0.002$, respectively. However, in the study by Rosołowska-Huszcz et al. (2001), significant correlation was found between saturated fatty acid $\left(\mathrm{C}_{14: 0}, \mathrm{C}_{18: 0}\right)$ or unsaturated fatty acid $\left(\mathrm{C}_{18: 1}\right)$ intake and the corticosterone level in the cytosol of heart muscle $(r=0.34, P<0.05$; $\mathrm{r}=0.42, \mathrm{P}<0.01$ and $\mathrm{r}=0.48, \mathrm{P}<0.002$, respectively) This means that the examined target organs are sensitive to dietary fatty acids and that these fatty acids significantly affect the process of corticosterone uptake by receptors in both organs.

The pattern of fatty acids in the diet consumed and the content of dietary cholesterol significantly affect the concentration of cholesterol in the blood (Grundy, 1989) and in individual tissues (Baldner et al., 1987). In a healthy organism, dietary cholesterol inhibits cholesterogenesis, mainly in the liver and small intestine. This mechanism plays a crucial role in maintaining homeostasis of cholesterol in the blood. Nonetheless, any differences in the type of diet consumed, mainly in the composition of fatty acids and cholesterol, may disturb cholesterol homeostasis. On the one hand, an elevated blood cholesterol level is often ascribed to an increase in the intake of saturated fatty acids (mainly $\mathrm{C}_{12: 0}-\mathrm{C}_{16: 0}$ ), cholesterol, and energy. On the other hand, mono- and polyunsaturated fatty acids have an opposite effect on blood cholesterol levels (Ghatak et al., 1992).

To date, a large body of studies has been undertaken to assess the influence of different fat types and levels in the diet on blood cholesterol concentrations, as well as on the concentration and synthesis of cholesterol in different tissues and organs, but the results are conflicting. Early and Spielman (1994) found that plasma cholesterol in rats was not affected by the type of dietary fat. On the other hand, in rats fed diets with higher fat levels, plasma cholesterol concentrations were higher. In contrast, in the study of Wiggers et al. (1977) plasma cholesterol concentration was fat-type dependent and was higher in rats fed diets containing fat rich in polyunsaturated fatty acids. However, in the present study we did not observe any difference in plasma cholesterol concentrations in experimental animals, although the fats of the diets offered to rats differed significantly in fatty acid composition and were from different sources.

Epidemiological human studies provide evidence of an association between the percentage of energy in the diet obtained from fat and increased body weight and body fatness (Golay and Bobbioni, 1997). However, in the present experiment and other studies performed in animals, feeding a high-fat diet resulted in an increased body fat content without significant changes in body weight (Boozer et al., 1995). Intriguingly, body fat accumulation may be influenced not only by the composition of diet fed to studied animals, but also by maternal high fat diet, as shown by Wu et al. (1998). 
In the present study, no difference in final body weight was found duc to fat type in the diet, consistent with the findings of Cha and Jones (1997). Body fat content tended to differ, however, between rats offered dicts containing lard and those consuming mixed fat diets. In epidemiological human studies, intake of animal fat was positively associated with weight gain, whereas intake of vegetable fat showed a negative association (Colditz et al., 1992). Wilson et al. (1990) showed that feeding high-fat diets (at least $25 \%$ energy as fat) to rats suppresses hepatic lipogenesis and that at this level of fat sunflower oil was more inhibitory than beef tallow. These findings could indicate different properties of animal and vegetable fats in promotion of weight gain and fat accumulation, which was shown in animals (Shimomura et al., 1991). Our data do not, however, support these findings, since no differences in body weight and fat content were found between rats fed high-fat diets containing fat of different origin (sunflower oil, lard or oil plus lard mixture).

\section{CONCLUSIONS}

The presented study clearly indicates that dietary fat and its composition affect corticosterone secretion, distribution and uptake by the target organs without any influence on plasma cholesterol concentration. Body composition is also affected by the amount and type of fat in the diet.

Having in mind, however, the importance of the issue, the problem necessitates further investigation.

\section{REFERENCES}

American Diabetes Association, 1987. Nutritional recommendations and principles for individuals with diabetes mellitus. Diabetes Care 10, 126-132

AOAC, 1960. Official Mcthods of Analysis of the Association of Official Agricultural Chemists. $9^{\text {th }}$ Edition. Washington, DC

Baldner-Shank G.L., Richard M.J., Beitz. D.C., Jacobson N.L., 1987. Effect of animal and vegetable fats and proteins on distribution of cholesterol in plasma and organs of young growing pigs. J. Nutr. 117, 1727-1733

Boozer C.N., Schoenbach G., Atkinson R.L., 1995. Dietary fat and adiposity: a dose-response relationship in adult male rats fed isocalorically. Amer. J. Physiol. 268, E546-550

Cha M.C., Jones P.J.H., 1997. Dietary fat type related changes in tissue cholesterol and fatty acid synthesis are influenced by energy intake level in rats. J. Amer. Coll. Nutr. 16, 592-599

Colditz G., Willet W., London S., Segal M., Speizer F., 1992. Patterns of weight change and their relation to diet in o cohort of healthy women. Amer. J. Clin. Nutr. 56, 616-622

Early R.J., Spiclman S.P., 1995. Muscle respiration in rats is influenced by the type and level of dietary fat. J. Nutr. $125,1546-1553$ 
Endozien J.C., Niehaus N., Mar M.H., Makoui T., Switzcr B.R., 1978. Diet-hormone interrelationship in the rat. J. Nutr. 108, 1767-1776

Elliot M.E., Goodfriend L., 1993. Mechanism of fatty acid inhibition of aldosterone synthesis by bovine adrenal glomerulosa cells. Endocrinology 132, 2453-2460

Ghatak A., Monte G., Garcia M., Tsushima M., 1992. Effects of dietary fatty acids and fibers on blood cholesterol. Jpn. J. Med. Sci. Biol. 45, 99-111

Golay T., Bobbioni E., 1997. The role of fat in obesity. Int. J. Obesity 21, Suppl. 3, S2-S11

Grundy S.M., 1989. What is desirable fat intake. In: G. Crepaldi (Editor). Atheroselerosis VIII, Elsevier Science Publisher, Amsterdam, pp. 665-672

Harris W.S., 1989. Fish oils and plasma lipids and lipoproteins in humans: a critical review. J. Lipid Res. 30, 785-807

Hegsted D.M., 1991. Dietary fatty acids, serum cholesterol, and coronary heart disease. In: G.J. Nclson (Editor). Health Effects of Dietary Fatty Acids. Champaign, American Oil Chemists' Society, pp. 50-68

Kunachowicz K., Nadolna J., Przygoda B., Iwanow K., 1998. Food Composition Tables (in Polish). lnstitute of Food and Nutrition, Warszawa (Poland), pp. 290, 312

Leaf A., Weber P.C., 1988. Cardiovascular effects of n-3 fatty acids. N. Engl. J. Med. 318, 549-557

Leibowitz S.F., Akabayashi A., Wang J., 1998. Obesity on a high - fat diet: role of hypothalamic galanin in neurones of the anterior paraventricular nucleus projecting to the median eminence. J. Neurosci. 18, 2709-2719

Lipid Research Clinics Program, 1984. The lipid rescarch clinic's coronary primary prevential trial results. JAMA 251, 351-374

Lowry O.H., Rosebrough N.J., Favy A.L., Randall O.P., 1951. Protein measurment with Follin phenol reagent. J. Biol. Chem. 193, 265-275

Malozowski S., Muzzo S., Burrows R., Leiva L., Loriaux L., Chrousos G., Winterer J., Cassorla F., 1990. The hypothalamic - pituitary - adrenal axis in infantile malnutrition. Clin. Endocrinol. 32, $461-465$

Mangold H.K., Bezzegh $\Upsilon$., 1974. Routine methods of lipid analysis. In: H.Ch. Curtius, M. Roth (Editors). Clinical Biochemistry. Principles and Methods. Walter de Gruyter, Berlin, pp. 1036-1037

Mensink R.P., Katan M.B., 1989. Effect of a diet enriched with monounsaturated or polyunsaturated fatty acids on levels of low - density and high - density lipoprotein cholesterol in healthy women and men. N. Engl. J. Med. 321, 436-441

Oliver M.F., Riemersma R.A., Thomson M., Wood D.A., 1989. Linoleic acid and coronary heart disease. In: G. Crepaldi (Editor). Atherosclerosis VIII. Elsevier Science Publishers, pp. $495-$ 499

Rosołowska-Huszcz D., Gromadzka-Ostrowska J., Wilczak J., Romanowicz K., Borysiak M., Dębska M., Mazurek B., 2001. Thyroid peroxidase and hepatic glucose-6-phosphate activity and corticosterone level in plasma and tissues in rats fed different dietary fat. J. Anim. Feed Sci. 10, 185 200

Sarel 1., Widmaier E.P., 1995. Stimulation of steroidogenesis in cultured rat adrenocortical cells by unsaturated fatty acids. Amer. J. Physiol. 268, R1484-1490

Shimomura Y., Tamura T., Suzuki M., 1991. Effect of dietary polyunsaturated fats on body fat accumulation. In: Romsos Dea (Editor). Obesity: Dietary Factors and Control. Jpn. Sci. Soc. Press/ Karger, Basel, pp. 191-198

Silvestre J.S., Robert V., Heymes C., Aupetit - Faisant B., Mouas C., Moalic J.M., Swynghedauw B., Delcayre C., 1998. Myocardial production of aldosterone and corticosterone in the rat. Physiological regulation. J. Biol. Chem. 273, 4883-4891

Sinclair H.M., 1984. Essential fatty acids in perspective. Hum. Nutr. Clin. Nutr. 380, 245-260 
STATGRAPHICS, version 4.1, 2000

Storlien L.H., James D.E., Burieigh K.M., Chisholm D.L., Kracgen E.W., 1986. Fat feeding causes widespread in vivo insulin resistance, decreased energy expenditure, and obcsity in rats. J. Biol. Chem. 251, E576-583

Stupnicki R., 1985. Glicocorticosteroids (in Polish). In: F. Kokot, R. Stupnicki (Editors). Radioimmunoassay and Radiocompetition Methods Applied in Clinics. PZWL, Warszawa, pp. 235-244

Tannenbaum B.M.M., Brindley D.N., Tannenbaum G.S., Dallman M.F., McArthur M.D., Meaney M.J., 1997. High-fat feeding alters both basal and stress-induced hypothalamic-pituitary-adrenal activity in the rat. Amer. J. Physiol. 273, E1168-1177

Widmaier E.P., Rosen K., Abbott B., 1992. Frec fatty acids activate the hypothalamic-pituitaryadrenocortical axis in rats. Amer. J. Physiol. 131, 2313-2318

Wiggers K.D., Richard M.J., Stewart J.W., Jacobson N.L., Berger P.J., 1977. Type and amount of dictary fat affect relative concentration of cholesterol in blood and other tissues of rats. Atherosclerosis $27,27-34$

Wilson M.D., Blake W.L., Salati L.M., Clarke S.D., 1990. Potency of polyunsaturated and saturated fats as short-term inhibitors of hepatic lipogenesis in rats. J. Nutr. 120, 544-552

Wu Q., Mizushima Y., Komiya M., Matsuo T., Suzuki M., 1998. Body fat accumulation in the male offspring of rats fed high-fat diet. J. Clin. Biochem. Nutr. 25, 71-79

Zimmet P.Z., Baba S., 1990. Central obesity, glucose intolerance and other cardiovascular risk factors: an old syndrome rediscovered. Diabetes Res. Clin. Pract. 10, S167 (Abstr.)

\section{STRESZCZENIE}

\section{Wplyw różnego rodzaju tluszczu w diecie na stężenie kortykosteronu w tkankach szczurów}

Badano wpływ diety różniącej się ilością (5 i 30\%) i rodzajem tłuszczu 1:1/wt (olej słonecznikowy, smalec $i$ ich równowagowa mieszanina) na stężenie kortykosteronu (Cs) w nadnerczach, mięśniu sercowym i aorcie szczurów, a także na poziom cholesterolu w osoczu krwi oraz skład chemiczny ciała.

Dieta zawierająca 5\% smalcu spowodowała istotny wzrost poziomu Cs w nadnerczach w porównaniu z dictą zawicrająca $5 \%$ oleju słonecznikowego oraz $5 \%$ mieszaniny tłuszczy. Znaczący wzrost poziomu hormonu w aorcie stwierdzono u szczurów, karmionych dictami zawierającymi 5 i $30 \%$ oleju słonecznikowego w porównaniu ze zwierzętami karmionymi dietami z taką samą zawartością smalcu lub mieszaniny tłuszczu. Stężenie Cs w mięśniu sercowym było wyższe u szczurów karmionych dietą z 5 i $30 \%$ zawartością oleju słonecznikowego w porównaniu z pozostałymi dietami.

Zarówno rodzaj tłuszczu w diecie jak $\mathrm{i}$ jego poziom nie wpłynęły w sposób istotny na stężenie cholesterolu w osoczu. W ciele szczurów karmionych dietami zawierającymi $30 \%$ thuszczu wyższa była zawartość suchej masy oraz thuszczu, a niższa białka i popiołu, w porównaniu ze zwierzętami karmionymi dietami o niższej zawartości tłuszczu. Rodzaj tłuszczu diety nie wpłynął w sposób istotny na skład ciała zwierząt ( $\mathrm{z}$ wyjątkiem zawartości suchej masy). 